\title{
PENGARUH TEKANAN DARAH TERHADAP AKTIVITAS FISIK LANSIA
}

\section{Effects of Blood Pressure on Physical Activity of the Elderyl}

\author{
Ika Sumiyarsi 1), Angesti Nugraheni ${ }^{2)}$, Sri Mulyani ${ }^{3)}$, Erindra Budi Cahyanto ${ }^{4}$, \\ Mujahidatul Musfiroh ${ }^{5}$ \\ *) Prodi Kebidanan Program Sarjana Terapan Fakultas Kedokteran Universitas Sebelas Maret \\ Surakarta
}

email: ikasumiyarsi@staff.uns.ac.id

\begin{abstract}
ABSTRAK
Latar belakang: Penambahan usia menyebabkan penurunan kemampuan lansia untuk beraktivitas. Penuaan usia merupakan faktor resiko terjadinya tekanan darah tinggi. Peningkatan tekanan darah dapat menurunkan aktivitas fisik lansia. Pengendalian tekana darah lansia sejak dini dapat meningkatkan usia harapan hidup seseorang. Tujuan penelitian ini untuk menganalisis pengaruh tekanan darah dengan aktivitas fisik pada lansia.

Subjek dan Metode: Jenis penelitian cross sectional. Subjek penelitian lansia 60-69 tahun. Instrument pengumpulan data menggunakan Kuesioner IPAQ Long version, Sphignomanometer jarum, stetoskop. Analisis data menggunakan somers'd..

Hasil: Uji Somers'd antara tekanan darah dan aktivitas fisik lansia menunjukan hasil $r=$ 0,321 dengan $\mathrm{p}$-value sebesar 0,05 .

Kesimpulan: Terdapat pengaruh antara tekanan darah dan aktivitas fisik pada lansia dengan korelasi lemah dan arah negatif. Semakin tinggi tekanan darah, aktivitas fisik lansia cenderung semakin rendah.
\end{abstract}

Kata kunci: Tekanan Darah, Aktivitas Fisik, Lansia 


\section{ABSTRACT}

Background: Increasing age causes a decrease in the ability of the elderly to move. Aging is a risk factor for high blood pressure. Increased blood pressure can reduce physical activity in the elderly. Control of the elderly's blood pressure early can increase one's life expectancy. The purpose of this study was to analyze the effect of blood pressure on physical activity in the elderly.

Subjects and Method: This type of research is cross sectional study. Elderly research subjects 60-69 years. Data collection instruments using the IPAQ Questionnaire Long version, Sphignomanometer needle, stethoscope. Data analysis using somers'd.

Results: Somers'd test between blood pressure and physical activity of the elderly showed $r$ $=-0,321$ with a p-value of 0.05 .

Conclusion: There is an influence between blood pressure and physical activity in the elderly with a weak correlation and negative direction. The higher the blood pressure, the physical activity of the elderly tends to be lower.

Keywords: Blood Pressure, Physical Activity, Elderly.

\begin{tabular}{l}
\hline \multicolumn{3}{c}{ PENDAHULUAN } \\
\hline Tekanan darah adalah kekuatan yang \\
dihasilkan dinding arteri dengan \\
memompa darah dari jantung ${ }^{[11]}$. \\
Peningkatan tekanan darah yang \\
berlangsung dalam waktu lama (persisten) \\
dapat menimbulkan kerusakan pada ginjal \\
(gagal ginjal), jantung (penyakit jantung \\
koroner), dan otak (menyebabkan stroke) \\
bila tidak terdeteksi secara dini serta \\
mendapat pengobatan yang memadai ${ }^{[13]}$. \\
Oleh sebab itu, penting untuk menjaga \\
kestabilan tekanan darah, salah satunya
\end{tabular}
dengan rutin melakukan aktivitas fisik.

Aktivitas fisik adalah gerakangerakan bagian tubuh yang meningkatkan penggunaan energi atau pemakaian kalori ${ }^{[9]}$. Menurut World Health Organization (WHO, 2010) aktivitas fisik terbagi menjadi 3 golongan yaitu rendah, sedang, dan berat. Proporsi aktivitas fisik penduduk Indonesia berdasarkan Riset Kesehatan Dasar (Riskesdas, 2013) secara umum masih tergolong kurang aktif (sedentari) yaitu 26,1\% .

Perilaku sedentari menurun seiring pertambahan usia, dan terjadi peningkatan kembali pada umur $\geq 50$ tahun (Riskesdas, 2013). Penelitian di Amerika menunjukkan bahwa pengurangan aktivitas sedentari sampai dengan $<3$ jam per hari dapat meningkatkan usia harapan hidup sebesar 2 tahun (Katzmarzyk dan Lee, 2012). Dengan kata lain, peningkatan aktivitas fisik dapat meningkatkan usia harapan hidup seseorang.

WHO (2016), memperkirakan peningkatan usia harapan hidup pada tahun 2025 jumlah lanjut usia (lansia) akan meningkat dua kali lipat. Indonesia akan memasuki periode lansia (ageing) di tahun 2020. Tercatat sekitar 8, 49\% dari total penduduk Indonesia saat ini adalah lansia. Jawa Tengah merupakan provinsi dengan persentase jumlah lansia terbanyak kedua yaitu sekitar $11,8 \%{ }^{[14]}$.

Lansia merupakan kelompok orang yang sedang mengalami suatu proses perubahan secara bertahap dalam jangka waktu tertentu ${ }^{[5]}$. Kelebihan berat badan merupakan permasalahan umum pada lansia. Hal ini meningkatkan resiko timbulnya penyakit salah satunya tekanan darah tinggi. Peningkatan tekanan darah diakibatkan berkurangnya elastisitas pembuluh darah serta berkurangnya aktivitas fisik lansia ${ }^{[7]}$.

Kurangnya aktivitas fisik mengurangi pengeluaran energi untuk metabolisme lemak, menyebabkan kelebihan berat badan dan berakibat otot jantung bekerja lebih keras untuk memompa darah dalam jumlah yang sama ke seluruh tubuh. Meskipun Kelebihan 
berat badan erat kaitannya dengan tekanan darah tinggi, tetapi tidak semua orang dengan kelebihan berat badan mengalami tekanan darah tinggi. Tergantung pada masing-masing individu ${ }^{[12]}$.

Data Dinas Kesehatan Surakarta tahun 2016, menunjukan jumlah lansia dengan indeks masa tubuh lebih terbanyak di wilayah Kelurahan Sumber yaitu 124 lansia. Hasil studi pendahuluan yang dilaksanakan pada 5 RW di Kelurahan Sumber didapatkan hasil 13 lansia dengan kelebihan berat badan, 1 lansia di antaranya mengalami hipertensi derajat 3 , 1 lansia mengalami hipertensi derajat 2, 5 lansia mengalami hipertensi derajat 1,2 lansia megalami pre hipertensi, dan 4 lansia dengan tekanan darah normal. Berdasarkan data tersebut peneliti tertarik untuk melakukan penelitian tentang hubungan aktivitas fisik dan tekanan darah pada lansia dengan kelebihan berat badan di Kelurahan Sumber.

Tujuan penelitian ini adalah untuk menganalisis hubungan antara aktivitas fisik dan tekanan darah pada lansia dengan kelebihan berat badan.

\section{SUBJEK DAN METODE}

Penelitian ini menggunakan metode observasional analitik dengan pendekatan cross sectional untuk mengetahui hubungan antara aktivitas fisik dan tekanan darah pada lansia dengan kelebihan berat badan. Penelitian ini dilaksanakan di Kelurahan Sumber pada bulan Januari-Juni 2017. Pengambilan data dilaksanakan pada bulan April- Mei 2017.

Populasi dalam penelitian ini adalah semua lansia di Kelurahan Sumber dengan kelebihan berat badan. Sampel penelitian diambil dengan teknik total sampling, yaitu seluruh responden dari populasi yang memenuhi kriteria restriksi, sebanyak 42 lansia.

Instrument pengumpulan data menggunakan Kuesioner IPAQ Long version, stetoskop, mikrotois Sphignomanometer jarum dan timbangan berat badan digital yang dikalibrasi oleh Balai Metrologi Kota Surakarta.

Pengumpulan data dilakukan dengan mengukur tinggi badan serta berat badan seluruh lansia untuk mengetahui besarnya Indeks Masa Tubuh (IMT). Lansia dengan IMT >25 diberi formulir biodata untuk mengetahui pemenuhan kriteria restriksi. Setelah didapatkan responden yang memenuhi kriteria restriksi, dilakukan pengukuran tekanan darah. Responden, diwawancarai menggunakan kuesioner IPAQ long version. Pengisian kuesioner dilakukan sebanyak 1 minggu sekali, selama 6 minggu. Pada minggu terakhir, dilakukan pengukuran tekanan darah Kembali.

Analisis data berupa analisis univariat dan bivariat. Analisis univariat dalam penelitian ini untuk mendiskripsikan karakteristik usia, jenis kelamin, pekerjaan, pendidikan, indeks masa tubuh, aktivitas fisik, dan tekanan darah. Analisis bivariat dilakukan untuk menganalisis hubungan antara aktivitas fisik dan tekanan darah pada lansia dengan kelebihan berat badan menggunakan uji Somers'd.

\section{HASIL DAN PEMBAHASAN \\ A. Karakteristik Responden \\ 1. Usia \\ Rentang usia responden 60-69 tahun, rerata usia 64,76 tahun dengan standar deviasi sebesar 3,392 dan nilai tengah 63,71 .}

\section{Jenis Kelamin}

Perempuan lebih banyak dibanding laki-laki, dengan persentase $88 \%$ (37 responden).

\section{Pekerjaan}

Sejumlah 64\% (27 responden) lansia tidak bekerja dan hanya sedikit responden yang bekerja sebagai karyawan swasta 14,3\% (6 responden).

\section{Pendidikan}

Sebagian besar responden berpendidikan rendah yaitu, 52,4\% (22 responden). 


\section{B. Tekanan Darah}

Tabel 2. Tekanan Darah Responden Berdasarkan Klasifikasi ESC/ESH 2013.

\begin{tabular}{ccc} 
Kategori & Frekuensi & Persentase \\
\hline Optimal & 3 & $7 \%$ \\
Normal & 8 & $19 \%$ \\
Pre Hiterpensi & 5 & $12 \%$ \\
Hipertensi Grade 1 & 13 & $31 \%$ \\
Hipertensi Grade 2 & 8 & $19 \%$ \\
Hipertensi Grade 3 & 5 & $12 \%$ \\
Total & 42 & $100 \%$ \\
\hline
\end{tabular}

Tabel 2 menunjukan sebagian besar responden memiliki tekanan darah dengan hipertensi grade 1, yaitu $31 \%$. Batas tekanan darah yang masih dianggap normal adalah kurang dari 130/85 $\mathrm{mmHg}$, sedangkan bila lebih dari 140/90 $\mathrm{mmHg}$ dinyatakan sebagai hipertensi, dan diantara nilai tersebut disebut sebagai normal-tinggi. Batas antara tekanan darah normal dan tekanan darah tinggi tidaklah jelas, sehingga klasifikasi hipertensi dibuat berdasarkan tingkat tingginya tekanan yang mengakibatkan peningkatan resiko penyakit jantung dan pembuluh darah $^{[21]}$.

Tabel 3. Distribusi frekuensi tekanan darah berdasarkan Klasifikasi Triyanto 2014.

\begin{tabular}{lcc}
\hline \multicolumn{1}{c}{ Kategori } & Frekuensi & Persentase \\
\hline Normal & 11 & 26,2 \\
Normal-Tinggi & 4 & 9,5 \\
Hipertensi & 27 & 64.3 \\
Total & 42 & 100 \\
\hline
\end{tabular}

Tekanan darah paling banyak adalah kategori hipertensi yaitu $64,3 \% \quad(27$ responden). Rahajeng dan Tuminah (2009), menjelaskan tingginya tekanan darah sejalan dengan bertambahnya umur, disebabkan oleh perubahan struktur pembuluh darah besar. Pada lansia, serabut kolagen di pembuluh darah dan dinding arteriol bertambah sehingga pembuluh darah tersebut mengeras, dan berkurang elastisitasnya. Hal ini menyebabkan peningkatan tekanan darah.
C. Aktivitas Fisik

Tabel 1. Aktivitas Fisik Responden

\begin{tabular}{lcc}
\hline Aktivitas Fisik & Frekuensi & Persentase \\
\hline Ringan & 11 & 26,2 \\
Sedang & 17 & 40,5 \\
Berat & 14 & 33,3 \\
Total & 42 & 100 \\
\hline
\end{tabular}

Aktivitas fisik responden didominasi oleh aktivitas fisik sedang sebanyak 40,5\% (17 responden). Seiring bertambahnya umur, kemampuan lansia untuk beraktvitas fisik akan berkurang $30-50 \%{ }^{[8]}$. Berbeda dengan hal tersebut, responden penelitian ini memiliki aktifitas fisik sedang karena sebagian besar responden 52,4\% (22 responden) memiliki pendidikan rendah. Aktivitas fisik cenderung lebih tinggi pada mereka yang memiliki tingkat pendidikan lebih rendah $^{[3]}$

Sejumlah 64,3\% (27 responden) lansia tidak bekerja. Berdasarkan hasil pengisian kuesioner menunjukan bahwa sebagian besar responden yang tidak bekerja adalah ibu rumah tangga yang mengasuh cucu. Hal ini membuat aktivitas fisik lansia cenderung meningkat.

Aktivitas fisik responden sebelum usia 60 tahun cenderung teratur, yaitu 64,2\% (27 responden). Aktivitas fisik teratur membantu mempertahankan elastisitas pembuluh darah, bahkan pada subjek yang telah berumur ${ }^{[17]}$.

\section{KESIMPULAN DAN SARAN}

1. Tekanan darah pada lansia dengan kelebihan berat badan di Kelurahan Sumber antara lain normal 26,2\% (11 responden), kategori normal-tinggi $9,5 \%$ (4 responden) dan hipertensi $64,3 \%$ (27 responden).

2. Intensitas aktivitas fisik pada lansia dengan kelebihan berat badan di Kelurahan Sumber antara lain memiliki aktivitas fisik ringan sebanyak 26,2\% (11 responden), sedang sebanyak $40,5 \% \quad(17$ responden), dan aktivitas fisik berat $33,3 \%$ (14 responden).

3. Hasil analisis data menggunakan uji somers'd didapatkan taraf 
signifikansi/ Asymp. Sig sebesar 0,05. Terdapat hubungan antara antara aktivitas fisik dan tekanan darah pada lansia dengan kelebihan berat badan di Kelurahan Sumber, dengan arah korelasi negatif serta kekuatan hubungan lemah (nilai $r=-0,321$ ).

\section{DAFTAR PUSTAKA}

1. AHA (2014). Small Weight Gain can Raise Blood Pressure in Healthy Adults. http:// news.heart. org/ smallweight- gain- can- raise- bloodpressure- in- healthy-adults/ - diakses November 2016.

2. Bell, TP. Mcintyre, KA. and Hardley, R. (2014). Effect of Long-Term Physical Exercise on Blood Pressure in an African American Sample. International Journal of Exercise Science 7(3) : 186-193.

3. BHFNC (2012). Factor Influincing Physical Activity in Older Adults. www bhf active. org. uk- diakses Januari 2017.

4. ESH dan ESC (2013). Essential Messages from 2013 ESH/ESC Guidelines for The Management of Arterial Hypertension. www. escardio. org/ guidelines- diakses januari 2017.

5. Fatmah (2010). Gizi Usia Lanjut. Jakarta: Erlangga, p: 8.

6. Herman. (2010). Pengaruh Latihan Terhadap Fungsi Otot dan Pernapasan. Jurnal ILARA 1 (2) : 2732.

7. Irianto K (2014). Gizi Seimbang dalam Kesehatan Reproduksi. Bandung: Alfabeta, pp: 541-2, 629.

8. Konita S, Azmi S, Erkadius. (2015). Pola Tekanan Darah Pada Lansia di Posyandu Lansia. Kelurahan Padang Pasir Padang Januari 2014.
Jurnal Kesehatan Andala. 4 (1): 269273.

9. Oenzil F (2012). Gizi Meningkatkan Kualitas Manula. Jakarta: EGC, pp:131-2.

10. Osher E dan Stern N. (2009). Obesity in Elderly Subjects: In sheep's clothing perhaps, but still a wolf. Diabetes Care. 32 (2): 398-402.

11. Potter PA, Perry AG (2010). Fundamentals of Nursing. Jakarta: Salemba medika, pp: 213, 567-8.

12. Purwanto B (2012). Hipertensi (Pathogenesis, Kerusakan Target Organ dan Penatalaksanaan. Surakarta: UNS Press, pp: 10-23.

13. Pusdatin (2014). Hipertensi. Jakarta: Departemen Kesehatan, pp: 2-6.

14. Pusdatin Lansia (2016). Situasi Lanjut usia (Lansia) di Indonesia. Jakarta: Departemen Kesehatan, pp: 2-4.

15. Rahajeng E dan Tuminah S. (2009). Prevalensi Hipertensi dan Determinannya di Indonesia. Majalah Kedokteran Indonesia. 59 (12): 580-587.

16. Riskesdas (2013). Jakarta: Badan Penelitian dan Pengembangan Kesehatan Kementrian Kesehatan RI, p: 124,177.

17. Sharkey BJ (2011). Kebugaran dan kesehatan. Jakarta: Raja Grafindo Persada, p: 14.

18. Sunkudon MC, Palandeng H, Kallo V, (2015). Pengaruh Senam Lansia terhadap Stabilitas Tekanan Darah pada Kelompok Lansia GMIM Anugerah di Desa Tumaratas $2 \mathrm{Kec}$. Langowan Barat Kab Minahasa. Ejournal Keperawatan (3) 1: 3-4.

19. Susanto. (2010). Cekal (Cegah dan Tangkal) Penyakit Modern. Yogyakarta: Andi, p: 28. 
20. Susilo, Ambarwati Y, Wulandari A (2011). Cara Jitu Mengatasi Hipertensi. Yogyakarta: Penerbit Andi, pp: 22, 41, 56, 57.

21. Triyanto E (2014). Pelayanan Keperawatan bagi Penderita Hipertensi Secara Terpadu. Yogyakarta: Penerbit Andi, pp: 7, 105.

22. WHO (2010). Global Recommendation On Physical
Activity For Health. Switzerland: WHO press, pp: 7-10.

WHO (2013). A Global Brief on Hypertension: Silent Killer, Global Public Health Crisis. http:// chronicconditions. The health well. info /search-results/ global- briefhypertension- silent- killer-globalpublic- health- crisis- diakses November 2016 